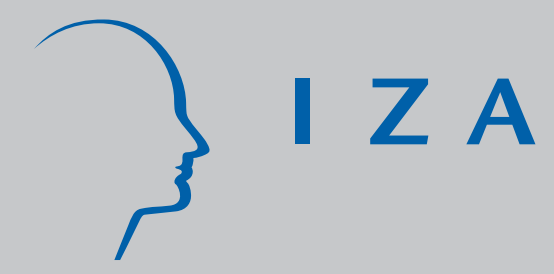

IZADP No. 2381

Politico-Economic Causes of Labor Regulation in the United States: Rent Seeking, Alliances, Raising Rivals' Costs (Even Lowering One's Own?), and Interjurisdictional Competition

J ohn T. Addison

October 2006 


\title{
Politico-Economic Causes of Labor Regulation in the United States: Rent Seeking, Alliances, Raising Rivals' Costs (Even Lowering One's Own?), and Interjurisdictional Competition
}

\author{
John T. Addison \\ University of South Carolina, Queen's University Belfast, \\ Universidade de Coimbra/GEMF and IZA Bonn
}

Discussion Paper No. 2381

October 2006

IZA

P.O. Box 7240

53072 Bonn

Germany

Phone: +49-228-3894-0

Fax: +49-228-3894-180

E-mail: iza@iza.org

Any opinions expressed here are those of the author(s) and not those of the institute. Research disseminated by IZA may include views on policy, but the institute itself takes no institutional policy positions.

The Institute for the Study of Labor (IZA) in Bonn is a local and virtual international research center and a place of communication between science, politics and business. IZA is an independent nonprofit company supported by Deutsche Post World Net. The center is associated with the University of Bonn and offers a stimulating research environment through its research networks, research support, and visitors and doctoral programs. IZA engages in (i) original and internationally competitive research in all fields of labor economics, (ii) development of policy concepts, and (iii) dissemination of research results and concepts to the interested public.

IZA Discussion Papers often represent preliminary work and are circulated to encourage discussion. Citation of such a paper should account for its provisional character. A revised version may be available directly from the author. 


\section{ABSTRACT}

\section{Politico-Economic Causes of Labor Regulation in the United States: Rent Seeking, Alliances, Raising Rivals' Costs (Even Lowering One's Own?), and Interjurisdictional Competition*}

This paper offers an eclectic survey of the political economy of labor regulation in the United States at federal and state levels along the dimensions of occupational health and safety, unjust dismissal, right-to-work, workplace safety and workers' compensation, living wages, and prevailing wages. We discuss rent seeking/predation, coalition formation, judicial review, and interjurisdictional competition as well as the implications of union decline. Our analysis should help dispel any notion that the U.S. labor market is unregulated while also indicating that the political process shows some sensitivity to benefits and costs.

JEL Classification: $\quad \mathrm{H} 70, \mathrm{~J} 28, \mathrm{J38}, \mathrm{J41}, \mathrm{J48}, \mathrm{J58}, \mathrm{J} 65, \mathrm{~J} 80, \mathrm{~K} 31$

Keywords: labor regulation, regulatory capture, interjurisdictional competition, judicial review, OSHA, unjust dismissals, workplace safety, right-to-work, living wage ordinances, prevailing wages, unionism.

Corresponding author:

John T. Addison

Department of Economics

Moore School of Business

University of South Carolina

1705 College Street

Columbia, SC 29208

USA

E-mail: ecceaddi@moore.sc.edu

\footnotetext{
* I thank without implicating Dennis Mueller and other participants of the conference The Effects of Interjurisdictional Competition on Regulation for their helpful comments on the first draft of this paper.
} 
A common error in popular expressions of political economy is the presumption that all firms oppose ... regulations because these edicts raise costs. The flaw in this presumption arises from an exclusive focus ... on the "direct effects" of regulation ...(T)he often pronounced heterogeneity among firms [also] gives rise to ... "indirect effects" - the competitive advantages that arise from asymmetrical distributions of regulatory effect among different groups of firms and workers. It is extremely important to recognize that for many firms and workers the indirect effects of regulation can outweigh ... the direct effects. (Bartel and Thomas, 1987, pp. 239-240.)

Our own research and experience with the issue of unjust dismissal indicate that employers and employer organizations have almost always opposed unjust-dismissal legislation. Except for the state of Montana, we know of no instances in which employers have taken the initiative to propose legislation in response to judicial decisions modifying the employment-at-will doctrine. (Stieber and Block, 1992, p. 792.)

No other kind of labor legislation [as workers' compensation] gained such general acceptance in so brief a period in this country. (Weiss, 1935, p. 575.)

Historically, supporters of unions ... have favored the primacy of federal law and regulations over state and local laws or regulations. The success of the living wage movement in galvanizing local sentiment suggests that groups favorable to labor might do well to rethink their preferences for national politics ... and consider the benefits of devolution of labor regulations to states and localities. (Freeman, 2005, p. 28).

Does anyone seriously believe that an efficient balance can be achieved through a political process? The flexibility to respond to the demands of market competition yields enormous benefits, but such benefits, because they tend to be diffused and delayed, have no organized constituency. So policies that restrict labor market flexibility create costs that are largely ignored politically. But these restrictions typically concentrate the benefits of security (protection from competition) on politically organized groups that will notice them and lobby hard for them, always in the name of fairness. (Lee, 1996, p. 103.)

\section{Introduction}

In this paper we discuss the political economy of labor regulation in the United States. As a practical matter, the subject has been neglected by labor economists who have almost exclusively focused on the effects of legislation. The determinants of regulation have tended only to be investigated in the context of potential omitted variables and simultaneous equations bias. The role of rent seeking in the political market place has 
rarely been carefully analyzed in the area of labor regulation. Rather, the tendency has been to assert and at best to infer such influence. In the cases of unemployment insurance and workers compensation, for example, the cross subsidization involved - respectively, from low- to high-unemployment industries and from low- to high accident industries has been argued to create incentives for those so subsidized to engage the polity, underscored by the phenomenon of rational ignorance. Similarly, it has been conventional to attribute national legislation on minimum wages to the congressional majority of northern states which coalesced to suppress competition from the smaller number of southern states paying lower wages and which in turn voted against the Fair Labor Standards Act. This strategy of raising rivals' costs has of course almost invariably been laid at the door of organized labor for virtually all labor regulation. That is, organized labor has always and everywhere been credited with supporting labor legislation as a means of raising the costs of nonunion labor and hence shifting demand in its favor (i.e. reducing competition for its jobs).

The U.S. situation is necessarily complicated by the fact that much labor legislation is state-originated/financed and administered. One of the strengths of federalism is said to be the opportunity it presents for the development of intergovernmental competition. The models of Tiebout (1956) and Oates and Schwab (1988) demonstrate the efficiency features of interjurisdictional competition, and a number of observers otherwise hostile to labor mandates see potential benefit in some such programs, most notably workers' compensation (from a transaction costs perspective). The argument is that the absence of federal influence admits of substantial variation across states that can permit experimentation that over time reveals desirable and undesirable feature, allowing the gradual evolution of the system (Bellante and Porter, 1990, p. 673). By the same token, there are undoubtedly negative effects (spillovers) that need to be addressed and a potential role for government in holding the ring and monitoring competition among states and local governments. These issues have been well rehearsed in the taxation literature (see for example Altemeyer-Bartscher and Kuhn, 2005; Wildasin, 1989, 2004; Wilson, 1986, 1999; Wilson and Wildasin, 2004), 2004), but to my knowledge have largely escaped serious consideration in the labor regulation literature. 
A further issue in labor regulation is the role of the common law. We will examine the view that legislation is a potential antidote in a federal system to the inefficiencies introduced by activist judiciaries. The issue here is the attenuation of a specific common law doctrine, but absent this there is also the basic issue of the costs of using the court system that we will address in the particular context of workers' compensation. But the idea that the courts have been more susceptible to capture than the legislature and that the switch to the latter at the beginning of the last century in the United States was an efficient response is left to others (see in particular Glaeser and Shleifer, 2003), even if the notion of differential subversion is encountered in addressing the efficacy of state versus federal legislation. Nor for that matter do we elaborate on the role of the courts as a vehicle for restraining overarching legislation at state (and federal) level. ${ }^{1}$

At this stage it seems premature to seek a unified framework for evaluating labor regulation in the United States (but for a general approach, see Amable and Gatti, 2004). Rather, we elect to provide information on several types of labor regulation at federal state and local level, each of which offers a different spin on regulatory behavior. We first examine the political economy of the Occupational Health and Safety Act to show the scope that exists for raising the costs of rivals by engaging the polity. We then turn to the case of unjust dismissals to show how regulation might be a corrective to the actions of interventionist judiciaries. Next, we tackle right-to-work legislation as an example of a partial political escape route affixed to national legislation. Only then do we consider state-level safety regulation and workers' compensation which arena offers the richest literature on the political economy of regulation and formal evidence on the use of regulation to raise rivals costs. Finally, we take a look at living wage ordinances and prevailing wages to update the minimum wage argument and identify the union 'interest.' In a concluding section, we draw together the threads of the preceding arguments.

\section{Themes in Labor Regulation}

(i) The Scope for Raising Rivals Costs: The Case of OSHA 
Perhaps the best estimates of the net benefits to (some) firms and workers ${ }^{2}$ of labor regulation are provided by Bartel and Thomas $(1985,1987)$ in the context of Occupational Safety and Health Administration (OSHA) regulations. The authors use the term "predation" to describe the actions of these interest groups. We focus here on the authors' analysis of the direct and indirect effects of complying with Occupational Safety and Health Administration (OSHA) regulations, as well as environmental Protection Agency (EPA) pollution abatement determinations. ${ }^{3}$ Recalling the first of our opening quotations, the direct effects of regulation are the partial equilibrium effects of workplace safety laws on individual firms and persons. The indirect effects stem from compliance asymmetries and enforcement asymmetries. Compliance asymmetries stem from economies of scale (smaller firms experience a larger unit-cost effect) and plant age, while enforcement asymmetries refer to regulations that are "systematically skewed" against particular groups of firms/workers. In each case, the authors have strong priors. The authors contend that there are strong economies of scale for compliance with OSHA regulations, and also that plants located in northern and midwestern states by virtue of their age would have higher compliance costs were the regulations evenly enforced (their own research pointing to regional enforcement asymmetries favoring these Frost-Belt firms, as well as more intensive enforcement against small and nonunion firms).

Bartel and Thomas (1987) evaluate the effects of regulation on total industry rents, namely, workers' wages and the price cost margin. The authors approximate the compliance costs of OSHA by the dollar value of penalties assessed for violations of safety standards (some 90 percent of the total) in 22 states, 1974-78. ${ }^{4}$ For the wage equation, these compliance costs are divided by the number of workers, for the price-cost margin they are divided by the value of shipments. The other key independent variables are plant size (percentage of workers in plants with 250 or more employees), the percentage of industry employment that is in the Frost Belt, and the percentage of workers in the industry covered by a collective bargaining agreement. Each is interacted with the regulation variable(s). For the wage equation, the controls include several characteristics of the workforce, average establishment size, overtime hours, research and development expenditures and advertising expenditure per employee, the four-firm 
concentration ratio, the annual growth in shipments, and year dummies. The union variable is interacted with the regulation argument and with the two intangible capital measures to detect evidence of differential rent seeking. The price-cost margin equation additionally includes various proxies for expenses, the value of assets again in relation to sales, and the annual growth in materials cost. Here the large firm and Frost-Belt variables are interacted with the regulation variable (and unionism).

The direct effects of OSHA regulations are obtained simply by suppressing the interaction terms. For the price-cost margin (wages) these direct effects are sizeable and negative (positive). Allowing for indirect effects based on the heterogeneity of regulatory cost burdens, the interaction terms between the regulation variable and the large firm proxy and a Frost-Belt location are both positive and well determined, reflecting compliance and enforcement asymmetries. Also as expected, the advantage of larger firms and a Frost-Belt location is attenuated in the presence of unionism: estimated at mean coverage, unions gobble up almost one-half of these regulation-induced rents. Turning to the wage equation, the interaction terms are again as expected: the coefficients for the firm size and regional interaction terms are positive and statistically significant. The direct effects of regulation on wages are now negative and well determined, but there is no indication of successful union dissipation of advertising rents (as was indicated in the price-cost margin equation).

To determine whether predators gain on net, the authors estimate the relative importance of the direct effects and indirect effect of the regulations at their mean values (and mean values of the dependent variables). Estimates are provided for minimum, mean, and maximum values of the large firm and Frost-Belt arguments. ${ }^{5}$ For an industry with the maximum share of workers in establishments with at least 250 workers, the reported net gain in profits is 2.9 percent; for an industry with the largest percentage of its workers in the Frost Belt the profits gain is 9.1 percent. The wage gains for unionized workers in these two settings are 3.2 and 3.8 percent, respectively. 
The bottom line from this study of federal legislation is that three distinct groups gain from federal regulation. The logical inference is that they may be expected to actively support OSHA/EPA legislation and that the indirect effects of regulation are indicative of predation rather than innocuous by-products of the public pursuit of workplace safety (Bartel and Thomas, 1987, p. 241).

\section{(ii) Legislation as a Corrective: The Political Compromise Hypothesis}

In an interesting discussion of unjust dismissal legislation in the United States at state level, Krueger (1991) argues that legislation is an antidote to the if not casuistic rulings of the American courts then certainly to the manner in which they have attenuated the common law (hire/fire) at-will principle. He seemingly accepts that the at-will doctrine would otherwise permit efficient transacting. Given the judicial innovations, however, there is scope for unjust dismissal legislation to clarify property rights to jobs and to reduce uncertainty/limit employer liability. He thus offers a second-best rationale for legislation.

His analysis proceeds at two levels. The first is a discussion of the origins of legislation in the one U.S. state - Montana - to have adopted an unjust dismissal statute; the other is an analysis of legislative proposals in all state legislatures linked to the degree of attenuation of the at-will principle. The former treatment identifies inter al. the large awards given to those adjudged to have been wrongfully dismissed in Montana, as well as other states (see also Dertouzos, Holland, and Ebener, 1988). Attention shifts in the cet. par. analysis to broader developments and in particular the (up to) three type of exceptions to at-will recognized in 41 state courts - the public policy, implied contract, and good faith exceptions - and the ten pieces of legislation that have been introduced in nine states, including Montana. The maintained hypothesis is that legislation can be expected to receive support from both sides of industry because the attenuation of at-will has produced uncertain and incomplete property rights to jobs and large transaction costs/highly variable awards in disputes over improper dismissals. Enter the political compromise hypothesis: unjust dismissal laws may be "an acceptable compromise between limited employer liability and assumption of fault” (Krueger, 1991, p. 653). The 
prediction is that legislation is more likely in states where exceptions have already been recognized by the courts.

Krueger provides logit regression estimates of the determinants of proposed legislation, 1981-88. In substitution for each (lagged) exception entered individually, in a final set of specifications he includes the total number of exceptions. Controls include the proportion of workers in a state who are union members, the proportion of Democrats in the state legislature, the proportion of state employment in manufacturing, and the state unemployment rate. On average, recognition of the public policy exception in a given year increases the probability that a state legislature will propose an unjust dismissal statute in the following by 8.5 percentage points, while a good faith exception increases it by 6.7 percentage points and an implied contract exception by 2.0 percentage points (although coefficient estimate on which this last estimate is based is poorly determined). For their part, the specifications using the total number of exceptions recognized in a state in a given year implies that each additional exception raises the probability of legislative innovation in the following year by approximately 5 percentage points. The coefficient estimates of all the other arguments are statistically insignificant. While arguing that laws may be an efficient alternative to an attenuated at-will doctrine, Krueger has to conclude that the threat to employers is not yet great enough to provoke sufficient support for proposed legislation to enter the statute books. One reason of course may be the heightened use of temporary or atypical workers not subject to the predations of the courts (see below).

Krueger's view has attracted controversy, most obviously because there is no attempt to model employer support. Another issue is whether the bills introduced into the nine state legislatures accurately portray employer support for legislation. Thus, for example, Stieber and Block (1992) argue that employers may have been reacting to other legislation that they had no hand in shaping and which arguably was more coercive. Krueger (1992, p. 797) counters that employers will be "less resistant" - or even reluctantly favor - legislation if the common law has been modified. In turn, this comment reveals the lingering imprecision of the argument. Why for example should the 
public policy exception be the seemingly most important exception? How costly has it proven in practice? And what were the differences between the four states in the sample recognizing all three exceptions - California, Connecticut, Montana, and Nevada - that led just one of them to enact the proposed legislation?

The most interesting conclusion of Krueger's (1991, p. 659) political compromise model is that the "threat to employers under the common law is not yet great enough in most states to provoke sufficient support for legislation.” As was hinted at earlier, one reason for this may be the growth in employment forms not subject in practice to judicial review, most notably temporary agency employment which has grown much faster than openended employment in the last three decades. Autor (2003) has recently examined the growth of the temporary help service (THS) industry between 1979 and 1995 and linked this to the erosion of the common law at-will principle. Using data the Census Bureau's County Business Patterns files and the ORG files of the Current Population Survey, he finds that THS employment is positively associated with the implied contract exception but not to the other exceptions in his favored fixed effects specification that also contains a set of state-specific time trends. This result, which is consistent with his priors, ${ }^{6}$ is robust to additional controls such as labor force demographics and the percentage of the state workforce that is unionized. (Interestingly, the latter coefficient estimate is negative and highly significant, indicating that temporary employment grew less rapidly in states where unions declined less - given the decline in union density of more than one-third over the sample period - which is of course consistent with union opposition to THS employment.) The bottom line is the finding that the implied contract exception contributed about 500,000 additional jobs (or some 20 percent) to the growth of THS employment. Independently, slower rates of union decline added to this total.

In Krueger (1991) the exceptions to at-will are taken to be exogenous. In a subsequent study of the state employment effects of these legal incursions, 1980-87, Dertouzos and Karoly $(1992,1993)$ argue that the probability of having one of the wrongful dismissal doctrines is strongly related with a number of state characteristics. Their instruments are whether a state had a right to work law (see subsection (iii) below), whether it had a 
Republican governor, the level and change in union density, the change in unemployment, the percentage of neighboring states recognizing a similar exception, the percentage change in lawyers per capita, and year dummies. They find that right-to-work states and those with a Republican governor (indicative of a conservative attitude toward labor) are less likely to have either a tort-based or contract-based exception, while the converse is true for the degree of unionization variable. There is also some evidence of spillover or yardstick competition: the higher the fraction of neighboring states that have recognized the respective doctrine, the more likely is the state to have the doctrine. The effect of the other instruments is either mixed or statistically insignificant.

Dertouzos and Karoly model the determinants of the exceptions to at-will in an attempt to provide unbiased estimates of their employment effects, since they argue there is simultaneous determination of the employment and the legal environment. Having instrumented the doctrine/remedy, the authors use the predicted values in place of the actual doctrines/remedy in the employment equation. Their principal finding is that aggregate employment is on average 2.9 (1.8) percent lower following a state's recognition of tort (contractual) damages for wrongful termination in a fixed effect model in which the regressors include gross state product and the growth in gross state product. The crucial issues here as elsewhere are that the instrument should have a direct causal impact on the exception to at-will and no effect on the outcome indicator other than through its influence on the at-will exception. As noted by Autor, Donahue, and Schwab (2001, pp. 33-35), two of the variables selected as instruments (court activities in neighboring states and the presence of a right to work law) have a substantial regional component relating to the South (the former negatively and the latter positively). Since the South has grown persistently faster than other U.S. regions since 1930, there is a correlation between the two instruments and preexisting growth rates which has the effect of biasing the results toward finding that wrongful discharge laws lower employment. Accordingly, the appropriate estimation strategy is to give each state its own time trend. In their replication of the Dertouzos and Karoly model including a linear state trend, Autor, Donahue, and Schwab (2001, Table 18) fail to obtain statistically significant coefficient estimates for the instrumented wrongful-termination doctrines. 
Nevertheless, the bottom line is that there is evidence of an employment cost to this form of employment protection, even if on the basis of Autor, Donahue, and Schwab's study this is less than suggested by Dertouzos and Karoly and applicable to an exception found to be statistically insignificant in Krueger's logit analysis of statutory innovations. ${ }^{7}$ Accordingly, the political compromise model might still have legs in the context of the attenuation of employment at will, and the absence of actual legislation reflect the levelof-costs argument advanced by its proponent.

\section{(iii) Right- to-Work Legislation.}

The 1935 National Labor Relations Act (NLRA) required employers to bargain in good faith with unions that represented a majority of their employees, and made it illegal for employers to impede their employees' right to organize. Further, section 8(c) of the NLRA allowed employer-union agreements requiring union membership as a condition of employment. The 1947 Labor-Management Relations Act (Taft-Hartley), which restricted some aspects of union activity (by identifying unfair labor practices on the part of unions), still permitted union (if not closed) shops but unequivocally authorized states to adopt right-to-work laws prohibiting these arrangements under section 14(b). As a matter of fact, 12 states had statutes prohibiting at least some forms of compulsory unionism prior to Taft-Hartley, so that the main technical legal effect of this section was to remove the possibility for unions to challenge right-to-work laws in court on grounds of federal supremacy.

Atypically, the determinants of right-to-work laws have been somewhat studied in the labor economics literature. But the purpose is again indirect: to obtain unbiased estimates of the effects of the law on several outcome indicators. Chief among these has been union membership, hypothesized to be reduced in the presence of right-to-work laws either by reason of increased union organizing and maintenance costs (as union shops cannot be used to curb free riding), or because of reduced bargaining power (stemming from the lack of universal membership within the bargaining unit) leading to reduced benefits from unionism and a long-run decline in membership. To the extent that right-to-work 
laws mirror existing but unobserved tastes for unionism and the extent of unionism, there is both an omitted variables problem and a simultaneous equations bias. The effects literature has therefore sought in often ingenious ways to control for the nonrandom presence of right-to-work laws (for surveys, see Moore and Newman, 1985; Moore, 1998).

Variables in the right-to-work equation have tended to reflect the simple view that employers favor and unions oppose such legislation. Union density is found to have a strongly negative impact on the likelihood that a state has a right-to-work law, although distinct employer arguments do not seem to have been deployed. Other variables have included economic development (poor states tend to adopt RTW laws to promote growth), degree of urbanization/population density (higher values for both of which are presumed to indicate 'collectivist views' facilitating the passage of legislation), and the proportion of the workforce that is female (higher shares are supposed for various reasons - tastes, labor force attachment, and job composition grounds - to favor right-to-work laws).

After taking the taste effects into account or treating the right-to-work status of states as endogenous, the point effects of the laws are often poorly determined. The same appears to be true of fixed-effect and disequilibrium models as well. One exception is Ellwood and Fine's (1987) fixed effect stock-adjustment model which suggests that right-to-work laws have a sizeable initial effect on organizing success that decays through time. And in several more recent studies this support for the notion that right-to-work laws may have real and not simply symbolic effects has gained ground somewhat (see below).

Interestingly, Ellwood and Fine also report that in the period before passage of a right-towork law union organizing activity is not depressed but is rather somewhat above average. They speculate that such laws may even be passed when unions are becoming stronger. Not dissimilar reasoning can be deployed to explain Taft-Hartley at the national level. That is, the unprecedented wave of strikes in the winter of 1945 and the first half of 1946, coupled with evidence of widespread union racketeering, may have brought about a 
consensus that the 1935 Act had been too one sided. On this view, Taft-Hartley went some way to even the scales (Baird, 1998, p. 482).

A similar line of reasoning also surfaces in an interesting case study of right-to-work campaigns in Louisiana in the 1940s, 1950s, and 1970s by Canak and Miller (1990), who focus on the involvement of business. The authors frame their study as a test of whether the two sides of industry are always in opposition or whether there is evidence of an historical accord between big business and labor. They conclude that typically both large and small businesses oppose unions but that some companies, again from both segments, mute their opposition when they perceive that unions are capable of effective retaliation. The link with the previous argument resides in Canak and Miller's contention that union organizing drives mobilized anti-labor organizations in each of the three decades examined. In the 1940s and 1970s larger companies in Louisiana played a public role in organizing and financing right-to-work campaigns. Their opposition became sotto voce in the 1950s, which new-found reticence the authors ascribe to pragmatic necessity: “The dominant [post-war] position of American business ... made it possible to enjoy fast growth and high profits. They feared business interruptions more than high wages and, therefore, avoided public support for RTW so as not to foster conflict with their unionized workers” (Canak and Miller, 1990, p. 264). What made the actions of business successful were inter-union divisions and, ultimately, international competition and redistricting. The actions in question are, sequentially, the passage of laws restricting union strikes activity, the passage of right-to-work legislation in 1954 and its repeal in 1956, and a new-right-to-work law in 1976.

We noted earlier that the modern literature points to there being some independent impact of right-to-work laws after all - although this is true for some measured outcomes (namely, union membership and union organizing) and not others (wages). The large sums spent by business interests in seeking such legislation, or resisting its repeal, would seem to indicate that rolling back union security has positive financial implications. A recent events study of shareholder wealth in response to the passage of the 1976 Louisiana law and a right-to-work law passed in Idaho in 1985 finds that the cumulative 
effect of enacting these laws was to increase the stock value of (the sample of 23) Louisiana firms by 2.2 to 9.5 percent and that of (12) leading Idaho firms by 2.4 to 2.9 percent (Abraham and Voos, 2000). ${ }^{8}$ This study offers support for the view that right-towork laws do matter, although it remains possible in both cases that the political debate helped shape public opinion against unions if not simply reflecting public opinion.

Currently, with the passage of Oklahoma's law in 2001, some 22 states have right-towork laws. Two-thirds of the laws were passed in the 1940s and 1950s in the immediate wake of Taft-Hartley. Equally, a large number of states had restrictions on union security prior to the Act, under state rules and judge-made law so that the early adoption of legislation was less of a sea change than might appear. Although sentiment in Congress now probably favors legislation, practicalities rule this out. Accordingly, the innovations at state level will have to substitute for national right-to-work legislation. To quote Baird (1998, p. 491): "the right-to-work battle will continue to be fought in the states, one state at a time, again and again.”

\section{(iv) The Case of Workplace Safety Reform and Workers' Compensation}

Some of the most interesting work on the political economy of regulation has documented the course of state-level safety regulation in mining and manufacturing, and the related reform of workers' compensation, introduced well in advance of the New Deal legislation. ${ }^{9}$ This literature identifies the circumstances where employers favored legislation to raise rivals' costs, but more generally pays close attention to the bargaining process between employers and workers. ${ }^{10}$ We examine safety regulation and workers' compensation in turn.

Workplace Safety Legislation. The pioneering study is Fishback's (2005) analysis of the role of large firms in influencing safety regulations in coal mines and factories, 18691930. He characterizes their strategies as either defensive (either opposing regulation outright or limiting the breadth of regulation) or predatory/subversive (raising rivals' costs). His focus is primarily on safety regulations rather than workers' compensation per se. (Fishback and Kantor (1995; 1996, 1998; 2000) focus exclusively on workers 
compensation which, as we shall see, is depicted as a 'win-win' situation for large firms, unions, and political reform groups, if not the insurance industry.) The strategies of large employers (establishments with 500 or more employees) are inferred to differ as between branches. It is expected that a strategy of raising rivals' costs will be associated with earlier adoption of state laws, wider regulation, and with more resources devoted to policing the regulations; and conversely for defensive strategies.

For manufacturing, he considers the determinants of the introduction of labor administrations (with and without coercive power) and factory inspectorates (to enforce the regulations). For coal mining, he considers the determinants of the introduction of coal mine safety laws, a regulation index based on a count of the number of mine regulations introduced, and the inspection budget.

The methodology for manufacturing is a Weibull hazard specification with time-varying regressors. The goal is therefore to address the timing of labor administration and factory inspectorate innovations. Apart from the proxy for large firms (average employment size), the regressors are manufacturing employment, either a union index (measuring the share of workers in manufacturing relative to the national average) or the number of union chapters, and a dummy for Southern states. It is found that the hazard ratios are greater than unity for larger firms, consistent with earlier adoption. Specifically, a one standard deviation increase in firm size is associated with a 31 (28) percent increase in the conditional probability of adopting some form of labor administration (factory inspectorate). Fishback argues that this finding is inconsistent with the view that large firms sought to obstruct legislation. The union hazard ratios are both mixed and poorly determined, so that it is difficult to conclude that they either contributed to or were opposed to legislation. One interpretation, and that favored by Fishback, is that unions were likely more interested in building up their organizational strength to obtain influence than to engage the polity.

Opposite results are obtained for coal mining in regressions estimated over a reduced number of states (with bituminous coal production). That is, larger mines are not 
associated with earlier adoption of coal safety legislation. This time, however, the union 'effect' exceeds unity and is statistically significant at conventional levels. Since the former result might indicate that "larger mines were indifferent to coal regulations or that they were unsuccessful in staving off the efforts of reformers” (p. 19), Fishback also estimates OLS and state and year fixed effect models of the determinants of the size of the inspection budget per coal worker and a coal mining law index capturing the reach of legislation. The size of mine argument is negatively associated with each outcome indicator. Union effects are measured by the share of the workforce in the United Mineworkers and are weak throughout, a result that might hint at inadequate inspections and (as before) induced self reliance to effect change. Fishback concludes that taken in the round his results for mining indicate that larger employers were successful in limiting the reach of legislation and in reducing inspection budgets.

At issue of course is why employers adopted a defensive strategy in one sector but not in the other. Fishback's answer exploits the disparate nature of manufacturing vis-à-vis mining (such that a common set of laws may have left many parts of the manufacturing sector unaffected); the more adversarial nature of industrial relations in coal mining, coupled with the fact that the reform proposals emanated largely from organized labor; and the virtual absence of women in coal mining (it being easier to 'sell' regulation for women and harder to obstruct regulation).

Workers' Compensation. State workers' compensation plans provide for employermandated no-fault insurance covering workplace injuries, coupled with limits on liability from lawsuits. The passage of workers' compensation laws in several states during the 1910s constituted one of the earliest and most important government interventions in the workplace. Currently, workers' compensation is compulsory in all but three states (New Jersey, South Carolina, and Texas). ${ }^{11}$ Workers are eligible for medical and partial indemnity (lost wage) benefits when disabled by job-related injury or illness. Employers are liable regardless of fault but may dispute the severity of an injury or illness or challenge whether it is work related. Workers compensation costs are nominally paid through employer payroll taxes (but see below). A few states require that employers 
insure through a state-operated insurance system. Many states operate a state system but permit insurance through private insurance companies or self insurance. (The system exhibits close to full experience rating in the case of larger firms.)

Prior to workers' compensation a system of common law negligence liability obtained. Employers were obligated to exercise "due care" in protecting their workers against hazards at the workplace. Employees bore the burden of proof, however, and had to demonstrate that the employer's negligence was the cause of the injury. A negligent employer might nevertheless rely on one of three legal escape routes, including contributory negligence.

The change from negligence liability to a no-fault system is well described by Fishback and Kantor (2000). They give chapter and verse on the high transactions costs (in money and uncertainty) to employers of using the courts and describe how 25-40 percent of any compensation awarded employees might be swallowed up in legal fees. Accordingly, they identify a broad consensus favoring reform and describe the outcome as a win-win situation - for all but trial lawyers. Disputation was over the details: state-run versus private insurance and the level of indemnity benefits. In the former area, organized labor lined up against the insurance companies (employers offered mixed support for a staterun insurance fund); in the latter organized labor and large employers were in obvious contention (but see immediately below). The outcomes were determined by variations in the political strength of these groups (see also Fishback and Kantor, 1996).

Additional insight into employer support for workers' compensation (and the speed with which the laws were enacted across most states) can be gleaned from an analysis of wages. Fishback and Kantor (1995) contend that although expected injury compensation rose considerably with the passage of the state laws - both as a result of more individuals receiving compensation and compensation levels that were considerably higher than under negligence liability - much or all of the employers' costs were shifted back onto employees. The authors construct three panels for relatively dangerous industries coalmining (1911-22), lumber (1910-13, 1915, 1921, and 1923), and union contracts in 
the building trades (1907-13) - in each case regressing hourly earnings in a state on an index of expected injury benefits (computed both prior to and after the introduction of workers' compensation) and a fairly wide set of controls (product prices or demand index, output per man, unionization, strike activity, and occupation dummies, etc). For coal mining the authors' fixed effect estimates suggest that workers not only paid for the sharply-stepped increase in their expected benefits but may also have fully paid the employers' costs of purchasing insurance to provide those benefits. In the lumber industry, there appears to have been a full wage offset. But in unionized business construction (and indeed unionized coalmining) the coefficient estimate for the expected benefits variable was statistically insignificant, indicating an absence of any downward adjustment. These results were broadly robust to specification and to sample (restricting the sample to states and years when workers' compensation was in effect.). Fishback and Kantor (1995, p. 737) conclude: “The presence of wage offsets for nonunion workers also helps solve one of the major puzzles in political economy of the passage of workers compensation [viz. the leadership taken by employer groups] ... Many employers may have supported the legislation in anticipation of passing a substantial portion of the costs onto their workers in the form of lower wages.”

Nevertheless, Fishback and Kantor (1998) also report that employers (while favoring workers compensation) and unions feuded over the issue of benefit levels, noting that where they were unable to reach a compromise the introduction of workers' compensation was delayed for up to 15 years! One reason for this is the failure to observe wage offsets in union settings, noted earlier. Employers of unionized labor may then have had a strong incentive to minimize the size of injury benefits that they paid. Further, we have seen that the cost of insurance was not fully shifted back on to (nonunion) workers outside of coalmining. Nor was this pass back instantaneous. In this later study, therefore, Fishback and Kantor focus attention on the determinants of their index of expected injury benefits, 1910-30. The key regressors are an index of the risk of accidents in manufacturing, an index of unionization in manufacturing, measures of the strength of farm and manufacturing interests, the proportions of large and small firms, and manufacturing value added per worker. In addition, as indicators of the 'political climate' 
the authors identify power shifts in the legislature, percent of the presidential vote for a republican candidate and for a socialist candidate, and the presence of a workers' compensation bureaucracy (instrumented). One of the most important findings is that states with higher manufacturing risk had lower benefit levels. In turn, this suggests that employers in the most dangerous industries had considerable strength in state legislatures, and used this influence to keep their overall accident costs down. That said, greater union density in a state and the presence of a bureaucratic agency to administer the law (the alternative was through the court system) were each associated with higher expected benefits, cet. par. There is also some indication in the authors' data that political party shifts in either one or both legislative chambers at state level were associated with higher benefit levels. But political attitudes as indexed through votes in national elections were unimportant in explaining benefits, which result the authors interpret as suggesting that the views of state-level political parties did not necessarily match those of their nationallevel parents. Fishback and Kantor supplement this analysis with case studies of the political battle over benefits in the states of Ohio, Minnesota and Missouri. These case studies offer a much more detailed investigation of the role of interest groups in shaping the final content of workers' compensation laws and the timing of those laws (see in particular the case of Missouri).

The bottom line with respect to both safety regulation and workers' compensation is that the bills that entered into law were "more evolutionary than revolutionary" and the result of compromises (Fishback, 1998, p. 760). The employer side had political clout and in order to secure legislation labor had in many instances to work with them or a subset of them. There was clearly no large-scale redistribution of income involved and even for unionized workers, where there is little evidence of wage offsets, employers may have made adjustments along other margins of the employment relationship. Efficiency may also have been served by workers' compensation. Risk-averse workers may have gained because of the difficulty of obtaining insurance privately under the prior system of negligence liability, while for the employer side savings in transaction costs were supplemented by the wage offsets. That said, we know of no study examining whether the variation in programs across states has promoted an efficient evolution of the system. 
We do know that more recent changes in employers' costs of workers' compensation in the 1970s and 1980s have continued to be largely shifted to employees in lower wages (Gruber and Krueger, 1990).

\section{(v) The Surprising Case of Living Wage Ordinances}

Living wage laws have been in operation in the United States since they were first introduced in Baltimore 1994. Today around 100 cities, counties, and school districts have such ordinances. They resemble minimum wage laws but differ in setting a higher wage (ranging from $\$ 8.25$ to \$13 per hour, compared with the national minimum wage of $\$ 5.15$ ) that is most often fixed with reference to the poverty line ( $\$ 8.70$ for a family of four with a single full-time earner). That said, they are much more highly restricted, usually covering city contractors and, at one-fourth the frequency, companies receiving business assistance from the city.

Just as with minimum wages, most of the literature covers the effects of such regulation on the wage/poverty outcome, although Neumark (2001) explores the notion that municipal unions organize to pass living wage laws as a form of rent seeking. Focusing on the narrow coverage of the laws, Neumark argues that these 'other interests' (the municipal unions) raise the wages that contractors must pay and thereby reduce the incentives for cities to contract out work ordinarily done by municipal employees. (His maintained hypothesis is that if the goal of ordinances is poverty reduction, they should be more general wage floors; on which more below.) Neumark examines the wage and employment consequences of living wage laws in 19 cities. But first he seeks some prima facie evidence of union involvement. To this end, he first conducts a simple Internet search, looking for joint mention of living wages and the cities concerned (i.e. those with the ordinances) and next adds a union descriptor (beginning with the AFL-CIO). A large share of the former number of hits included the AFL-CIO, or a specific union; most were for two unions that play a prominent role in organizing local government workers: the American Federation of State, County, and Municipal employees (AFSCME) and the Service Employees International Union (SEIU). In a final step, he looks for evidence of 
union advocacy for living wages in the material, and cites some such instances of involvement.

Neumark's cet. par. analysis uses quarterly data from the CPS ORG files from January 1996 through December 2000. The match is SMSAs for cities, an imperfect fit since suburban residents may work in the city; it is local government employees for municipal workers, which is again an imperfect match as some individuals may work for units of government below state level. The sample is restricted to SMSA individuals aged 16-17 years. The dependent variables are (a) the share of unionized municipal workers in the city's labor force, and (b) the wages of unionized municipal workers. It is expected that living wage laws reduce the incentive to contract out, thereby raising the city-level employment share of unionized municipal workers. This is dubbed a 'strong test' because the more obvious result may simply be an increase in union bargaining power, rather than in contracting behavior. This leads to the second and weaker test, which is that this enhanced bargaining power only impacts wages. It is anticipated that markets for lowwage unionized workers - specifically, those earning less than the median wage - will be most impacted. The methodology is difference-in-differences. Formally, the right-handside variables are the higher of the federal or state minimum wage, and the city living wage, as well as the city and year (and quarter) dummies. All wage variables are in logs and are converted to hourly equivalents.

There is no evidence that the share of the workforce made up of unionized municipal workers - the strong test - is affected by the living wage, irrespective of whether or not a distinction is drawn between low-wage (i.e. below-median) unionized municipal workers and independent of the lags on the living wage and minimum wage arguments. However, for the weaker test, namely, that living wages will boost the wages of unionized municipal workers, there is evidence that living wages ordinances boost union pay both contemporaneously and with a 4-quarter lag. For below-median unionized municipal workers, living wages exceeding the minimum wage by 30 percent - which apparently is not uncommon (see also Adams and Neumark, 2005, Table 1) - would have the effect of raising the wages of union workers by around 4.5 percent. It is reported that living wages 
do not influence the earnings of 'municipal worker groups' for whom they are not expected to apply (e.g. teachers and police), which gives us some confidence in the prior results, and also that the positive earnings effect on union wages holds for the center of the wage distribution but not the extremes (substituting percentiles from the $30^{\text {th }}$ to the $90^{\text {th }}$ for the median), suggesting some fragility of the wage result. ${ }^{12}$

Further, case studies of living wage ordinances in Los Angeles, San Jose, Oakland, and San Diego by Zabin and Martin (1999) call into question the test used by Neumark (2001), while offering some political insights. In the first place, the authors see the narrow scope of living wage ordinances as strategic - helping guarantee success - and as providing a basis for expansion from service contractors through recipients of direct subsidies, loans and or tax breaks through to holders of public leases and different agencies (port authorities, airports, redevelopment agencies and other local government bodies), and product suppliers. The inevitability of gradualness - a phased extension of coverage - is necessitated by the "fragmentation of local government and the sheer number of public funding streams in an urban economy” (p. 31). The union role is also perceived very differently from Neumark: unions are directly tied to the effectiveness of the ordinances. Living wage laws are either targeted to cover groups that are likely to be organized or have recently been organized. Ordinances are also linked to related laws that help the climate for unionism such as labor peace laws. So the regulations are seen as structured to support union organizing. Next, the case studies link the success of living wage campaigns to inclusive coalitions of unions and community organizations (after admittedly fractious relationships in the 1960s and 1970s). Low-income peoples' organizations and unions are said to be now organizing the same communities, and laborcommunity coalitions are portrayed as instrumental to the formulation and passage of living wage ordinances. Links to national associations on each side of the coalition and integration of platforms, preferably in hybrid organizations, are also identified as important ingredients of success. Finally, living wage ordinances have to be rooted in a broader "growth with equity" agenda, encompassing economic justice, high road competition and redevelopment/industry clusters. 
Subsequent analysis has focused a little more on the political dimension. We noted earlier the importance of the involvement of a variety of organizations/coalition building to the passage of living wage laws. Luce (2005) reports that the involvement of the parties also carries over to the enforcement of the ordinances: implementation is weaker (less worker monitoring and more firm waivers) when left solely to city administrators. Stronger enforcement is duly reflected in stronger wage effects (see below). Interestingly, although seven states have acted to prevent cities from establishing their own minimum wages, there are no signs that the living wage movement is in retreat and the number of cities with living wage laws has continued to grow in the present decade at the same pace as in the 1990s. Freeman (2005, p. 17) links this success to nonworker organizations, arguing that "[living wage] campaigns succeed in part because citizen's find it easier to engage about local economic issues that about abstract national economic issues, and in part because the campaigns can produce fine-tuned and economically efficient pay increases.” By the latter remark, he is referring to the fact that most studies (at establishment level) ${ }^{13}$ have found that living wages occasion little loss of employment despite the pay increases, so he regards them as efficient tools for redistribution. By the same token, he is concerned by the relatively small numbers of workers affected by living wages, and advocates that living wage campaigns 'scale up.' Interestingly, Freeman sees greater potential for reforms at local level than at the national level. The vehicle is to be 'creative use' of procurement policies (see next subsection), their potential popularity being flagged by the success of living wage policies.

Finally, evidence with a bearing on some of the above arguments and inferentially on yardstick competition in living wages is contained in recent analysis of CPS data. ${ }^{14}$ In a paper stimulated by the odd finding that living wage laws applying to city contractors do not raise wages but that ordinances applying also to employers receiving business assistance (financial assistance, tax abatements, low interest loans, etc.) from the city do have this effect. ${ }^{15}$ Adams and Neumark (2005) examine the contribution of their differential enforcement and geographical concentration to the wage (and employment) outcomes of living wage ordinances. The authors deploy monthly CPS data (for 1996 to 2002) to estimate wage and employment regressions for low wage (bottom decile) 
workers across cities and over time, using a difference-in-differences methodology. Consistent with their earlier research (Neumark and Adams, 2003a, 2003b), it is reported that the hourly wages (employment) of those in the bottom decile are positively (negatively) related to living wages where the ordinance also covers businesses receiving business assistance (i.e. does not just apply to city contractors). Furthermore, irrespective of coverage, the wage and employment differences between cities are increased when ordinances are accompanied by living wages in nearby cities and where living wages are more broadly enforced. But the stronger effects for business assistance ordinances than for contractor-only ordinances are not produced by differences in enforcement; rather, for wages at least, it is whether or not nearby cities have living wage laws that seemingly accounts for the result that business assistance ordinances have stronger effects than contractor-only ordinances. For employment, negative effects are amplified for both types of ordinance and they are substantial.

\section{(vi) A Postscript on Prevailing Wage Laws}

Prevailing wage laws at state level requiring construction workers on state-funded works projects be paid at levels prevailing for similar work in the geographic area of the project largely postdate federal legislation in the form of the 1931 Davis-Bacon Act ${ }^{16}$ (although eight states enacted wage laws between 1891 and 1923). As of 1969, 40 states had prevailing wage laws on the books.

Analysis of the effects of federal regulation on wages and construction costs confronts an identification problem - average wages in a location are themselves a function of the prevailing wage - so that research has shifted to exploit differences in state prevailing wage regulations (Thieblot, 1986). The most recent research focuses on the nine states that repealed their prevailing wage laws between 1969 and 1993. Kessler and Katz (1999) compare wage outcomes in repeal and non-repeal states (excluding Minnesota which passed prevailing wage legislation in 1973) using a difference-in-differences-in differences methodology and individual data from the Census and the CPS. So the test is essentially the difference between the change over time in the relative blue-collar construction/non-construction wage in the two sets of states. It is reported that repeal is 
associated with a decline in the relative wages of construction workers of between 2.3 and 3.9 percent. For union members however the relative wage premium on construction work is reduced by 5.9 percentage points, which effect increases to 11.2 percentage points after five years. Even if the immediate outcome gives the better estimate of the equilibrium effect of repeal the outcome is still major, the union premium being in the order of 20 percent.

This careful study provides insights into the opposition of unions to repeal of state prevailing laws and an indication of the rent seeking that is involved in their passage. What is lacking is an equally careful analysis of the political economy of repeal.

\section{Conclusions}

Many of the labor laws that we now have on the books were adopted prior to the New Deal: limits on child labor, limits on working time, safety legislation, and workers' compensation laws. As we have seen, the causes of some of these early pieces of legislation at state level have been analyzed and with them the bargaining process between employers and workers as filtered through state-level politics. Interestingly, we have far less information on the political economy of national labor mandates, since the modern preoccupation has been to analyze the effects of legislation. Viewed from this imperative, the causes of mandates have only been examined in the interests of obtaining unbiased estimates of their consequences. Auxiliary equations apart, the political involvement of the labor and product market actors have been adduced from the payoffs to them of legislation. Another line of inquiry has been opened up by the actions of the courts. At the broadest level, legislation has been seen as a broad antidote to the 'subversion' of the courts. Less dramatically, individual pieces of legislation have been sponsored because of the high transactions costs of using the courts. On the other hand, recourse to the law has also been seen as a remedy for overarching state and local legislation. 
In reviewing the effects of U.S. labor legislation, Addison and Hirsch (1997, p. 166) conclude that workplace mandates may have rather muted benefits and costs, noting that the effects of mandates are mitigated in part through market escape routes, the shifting of costs, and the mobility of resources, and in part via a political process that shows some sensitivity to both benefits and costs. Our discussion of rent seeking, codification, coalitions, judicial review, and interjurisdictional competition gives some credence to this position, without of course claiming that the regulations generally work well or consistently for employers and employees (or even regulators). As a case in point, yardstick competition may have very different welfare implications in the area of labor regulation than it does for product market regulation.

Lest our limited discussion of national mandates still convey the impression that the U.S. labor market is unregulated at the federal level, however, let us dispel that notion by observing that by the mid-1990s the U.S. Department of Labor was administering some 180 regulatory programs covering labor standards, civil rights, occupational health and safety, labor relations, and hiring and separation decisions (see Commission on the Future of Worker-Management Relations, 1994a, b). At the time of the New Deal experiment the corresponding frequency was 18 and it was still only 40 as late as 1960.

Thus, it is no exaggeration to say that there has been a rapidly expanding role of government and the courts in providing workers with rights and protections in the workplace. This development has moreover coincided with a marked decline in unionism. The feedback from laws to reduced unionism is difficult to pin down, but it seems inevitable that protection against various forms of discrimination, and legislation on worker safety, advance notice of plant closings, and mandated family leave have contributed to the reduced demand for unionism. In much of our discussion the maintained hypothesis has been that high union density strengthens the political influence of unions on legislation. Now the argument is the other side of the coin: further reductions in unionism are likely to yield increased reliance on government to define rights at the workplace. 
These prospects engender little enthusiasm because it is widely accepted that the system of employment protection is costly, intrusive, and overly litigious. Reform proposals are in the wing, centering on notions of conditional deregulation and so-called market based systems of enterprise rights (see, respectively, Levine, 1997; Edwards, 1997). Since these proposals seek to deliver a balance between flexibility/productivity and fairness, they inevitably return us to Dwight Lee’s (1996, p. 103) admonition: "Does anyone seriously believe that an efficient balance can be achieved through a political process?” But we are not speaking of the first best and arguably heightened globalization will play an important role in the process.

By the same token, it may now be easier/cheaper for unions and their supporters to engage state legislatures than Congress. We saw some indication of this in our discussion of living wage laws. Indeed, Richard Freeman (2005, p. 28) exhorts unions to "rethink their preference for national politics and regulation and "consider the benefits of devolution of labor regulations to states and localities" and, more concretely, to scale up living wage campaigns. Any such redirection may be expected to threaten or reverse the liberalization of superannuated legislation that we have detected at state level, beginning of course with prevailing wage legislation in construction. 


\section{Endnotes}

1. Although it is as well to point out that the plethora of state bills seeking to restrict outsourcing (usually by banning the state from contracting with companies planning to employ offshore workers) would, if passed, likely succumb to legal challenge under the U.S. constitution on the grounds that they violate the Foreign Commerce Clause (Art. 1, §8, cl. 3). This clause restricts the states’ power to interfere with interstate or foreign commerce. By the same token, even if never enacted into law, such bills may already have had a chilling effect on the growth of information technology outsourcing by local and state governments.

2. On the magnitude of worker rents in the regulated trucking and airline industries, see Hirsch and Macpherson (1998, 2000).

3. On the competing interests involved in environmental protection per se and the effects of EPA regulation on factor shares and the size distribution of firms, see Pashigian (1984, 1985).

4. As a practical matter, the authors restrict the effects of OSHA and EPA regulation to have the same proportional relationship within each equation. For the price cost margin (wages), the former effect is roughly 9 (31) percent of the latter.

5. To simplify the discussion, I have neglected the issue of import competition. This study does include a measure of import penetration and finds that firms facing strong competitive pressures from imports are badly hurt by regulation. Specifically, where the value of industry net imports to shipments is at its maximum value (40 percent), the effect of regulation is reduce profits by almost one half (49 percent).

6. Violations of the public policy and good faith doctrines are actionable irrespective of the identity of the employer, while staffing arrangements (such as temporary help) cannot be used to shield firms from civil rights compliance. So there are no advantages to temporary employment here. Only the implied contract exception offers relief in so far as THS employment is ipso facto temporary (other than for the line staff of the temporary employment agency itself).

7. The main part of Autor, Donahue, and Schwab's (2001) study is devoted to the effect of the public policy, implied contract, and good faith exceptions upon state employment and wages, using data from the CPS monthly files, 1978-1999. Inconsistent with Krueger 
(1991), the authors find a statistically significant negative effect of the public policy exception on wages, suggesting that workers pay for the attenuation of at-will in one of the two categories deemed important by Krueger in generating proposals for an unjust dismissal statute. Consistent with Autor (2003), the authors find no reduction in wages associated with the implied contract exception and a small negative effect on employment (which adverse effect is strongest for less-educated males and younger workers).

8. For a review of studies examining the role of right-to-work laws in state industrial development, see Moore (1998, pp. 460-463).

9. In addition to safety regulation and workers' compensation, states also successfully introduced legislation limiting the hours of children and women. The laws seemingly had little independent impact, the main influence behind observed reductions in hours being technology (e.g. Goldin, 1990) In reviewing this literature, Fishback (1997, pp. 45) speculates that among the prime movers were those firms who had earlier most reduced their child labor and male-intensive industries respectively.

10. Progressive era reformers also figure in Fishback's model, and are depicted as seeking to impose reforms on larger employers.

11. Observe that even in these states most employers choose voluntary coverage so as to limit their liability

12. Why the very lowest paid union workers are unaffected by the ordinances is something of a puzzle.

13. See the summary contained in Fairris and Reich (2005).

14. There is controversy over the use of CPS to measure living wage outcomes largely because it does not identify the actual beneficiaries of living wage campaigns (see Freeman, 2005, fn. 15).

15. And also result in reduced employment and lower poverty (see Neumark and Adams, 2003a, 2003b).

16. Stigler (1970) and Heller (1986) contend - but do not test the argument - that federal minimum wages introduced under the Federal Fair Labor Standards Act in 1938 were passed by the Congressional majority of northern states, wherein the envisaged minima were generally exceeded, so as to extinguish low-wage competition from the southern states who voted against the legislation. The raising rivals' costs argument is yet more 
transparent in the case of prevailing wage legislation. In justifying the first draft of the bill in 1927, Congressman Bacon stated:

“The Government is engaged in building in my district a Veteran's Bureau hospital ... Several New York contractors bid, and in their bids, of course, they had to take into consideration the high labor standards prevailing in the State of New York ... The bid, however, was let to a firm from Alabama who had brought several thousand non-union laborers from Alabama into Long Island, N.Y., into my district. They were herded onto this job, they were housed in shacks they were paid a very low wage, and the work proceeded ... It seemed to me that the federal Government should not engage in construction work in any state and undermine the labor conditions and the labor wages in that State ... The least the federal government can do is comply with the local standards of wages and labor prevailing in the locality where the building construction is to take place.” (U.S. Congress, 1927.)

Bacon's proposal was eventually enacted into law in 1931, and it took another four years before the definition of the prevailing wage was determined. While we know of no formal analysis of the political economy of Davis-Bacon, the facts are that the regulations, and the manner of their enforcement, meant that wages were often set according to the union scale and that a 1935 amendment of the Act reduced the minimum contract amount covered to $\$ 2,000$ (as sought the union movement). More recent criticism of Davis-Bacon has centered on its purported discriminatory intent: on the facts that the Alabama construction workers in question were black (contested) and most major construction workers at that time excluded blacks (uncontested) (cf. Bernstein, 1993; Philips, Mangum, Waitzman, and Yeagle, 1995; see also Kessler and Katz, 1999). 


\section{References}

Abraham, Stephen E., and Paula B. Voos (2000), 'Right-to-work laws: new evidence from the stock market', Southern Economic Journal, 67, 345-62.

Addison, John T., and Barry T. Hirsch (1997), 'The economic effects of employment regulation: what are the limits?' in Bruce E. Kaufman (ed), Government Regulation of the Employment Relationship, Madison, WI: Industrial Relations Research Association, pp. 125-78

Adams, Scott, and David Neumark (2005a), 'The effects of living wage laws: evidence from failed and derailed living wage campaigns', IZA Discussion Paper No. 1566, Bonn.

Adams, Scott, and David Neumark (2005b), 'When do living wages bite?' Industrial Relations, 44, 164-192.

Altemeyer-Bartscher, Martin, and Thomas Kuhn (2005), 'Incentive-compatible grants-inaid mechanisms for federations with local tax competition and asymmetric information', unpublished paper, Chemnitz University of Technology.

Amable, Bruno, and Donatella Gatti (2004), 'The political economy of job protection and income distribution’, IZA Discussion Paper No. 1404, Bonn.

Autor, David H. (2003), 'Outsourcing at will: the contribution of unjust dismisssal legislation to the growth of employment outsourcing', Journal of Labor Economics, 21, 1-42.

Autor, David H., John J. Donahue III, and Stewart J. Schwab (2002), 'The costs of wrongful discharge laws’, unpublished paper, Massachusetts Institute of Technology.

Baird, Charles W. (1998), 'Right to work before and after 14(b)', Journal of Labor Research, 19, 471-93.

Bartel, Ann P., and Lacy Glenn Thomas (1985), 'Direct and indirect effects of regulation: a new look at OSHA’s impact', Journal of Law and Economics, 1, 1-25.

Bartel, Ann P. and Lacy Glenn Thomas. 1987. "Predation through regulation: the wage and profit effects of the Occupational Health Administration and the Environmental Protection Agency', Journal of Law and Economics, 30, 239-64. 
Bellante, Don, and Philip K. Porter (1990), 'A subjectivist economic analysis of government-mandated employee benefits', Harvard Journal of Law and Public Policy, 13, 657-87.

Bernstein, David. 1993. “The Davis Bacon Act: let's bring Jim Crow to an end.” Cato Briefing Paper No. 17, January 18.

Canak, William, and Berkeley Miller (1990), 'Gumbo politics: unions, business and Louisiana Right-to-Work legislation', Industrial and Labor Relations Review, 43, 258-71.

Commission on the Future of Worker-Management Relations (1994a), Fact Finding Report, Washington, DC: U.S. Department of Labor and U.S. Department of Commerce.

Commission on the Future of Worker-Management Relations (1994b), Report and Recommendations, Washington, DC: U.S. Department of Labor and U.S. Department of Commerce.

Dertouzos, James N., Elaine Holland, and Patricia Ebener (1998), 'The legal and economic consequences of wrongful termination', Rand Corporation document R3602-ICJ, Santa Monica, CA: The Rand Corporation.

Dertouzos, James N., and Lynn A. Karoly (1992), Labor-Market Responses to Employer Liability, Santa Monica, CA: The Rand Corporation.

Dertouzos, James N., and Lynn A. Karoly (1993), 'Employment effects of worker protection: evidence from the United States', in Christoph F. Buechtemann (ed), Employment Security and Labor Market Behavior - Interdisciplinary Approaches and International Evidence, Ithaca, NY: ILR Press, pp. 215-27.

Edwards, Richard (1997), 'Alternative regulatory approaches to protecting employees' workplace rights', in Bruce E. Kaufman (ed), Government Regulation of the Employment Relationship, Madison, WI: Industrial Relations Research Association, pp. 403- 27.

Ellwood, David T., and Glenn Fine (1987), 'The impact of right-to-work laws on union organizing', Journal of Political Economy, 95, 250-73. 
Fairris, David, and Michael Reich (2005), 'The impacts of living wage policies: introduction to the special issue', Industrial Relations, 44, 1-13.

Fishback, Price V. (1998), 'Operations of 'unfettered' labor markets: exit and voice in American labor markets at the turn of the century', Journal of Economic Literature, 36, 722-65.

Fishback, Price V. (2005), 'The irony of reform: did large employers subvert workplace safety reform, 1869 to 1930?' NBER Working Paper No. 11058, Cambridge, MA: National Bureau of Economic Research.

Fishback, Price V., and Shawn Everett Kantor (1996), 'A prelude to the welfare state: compulsory state insurance and workers' compensation in Minnesota, Ohio, and Washington, 1911-1919,' Journal of Economic History, 56, 809-36.

Fishback, Price V., and Shawn Everett Kantor (1995), 'Did workers pay for the passage of workers' compensation laws?' Quarterly Journal of Economics, 110, 713-42.

Fishback, Price V., and Shawn Everett Kantor (1998), 'The political economy of workers' compensation benefit levels, 1910-1930', Explorations in Economic History, 35, 109-39.

Fishback, Price V., and Shawn Everett Kantor (2000), A Prelude to the Welfare State: The Origins of Workers' Compensation, Chicago, IL: University of Chicago Press.

Freeman, Richard B. (2005), 'Fighting for other folks' wages: the logic and illogic of living wage campaigns', Industrial Relations, 44, 14-31.

Glaeser, Edward L., and Andrei Shleifer (2003), 'The rise of the regulatory state', Journal of Economic Literature, 41, 401-25.

Goldin, Claudia (1990) Understanding the Gender Gap: An Economic History of Women, New York, NY: Oxford University Press.

Gruber, Jonathan, and Alan B. Krueger (1990), 'The incidence of mandated employerprovided insurance: lessons from workers' compensation insurance', NBER Working Paper No. W3557, Cambridge, MA: National Bureau of Economic Research.

Heller, Thomas (1986), 'Legal theory and the political economy of American federalism', in M. Caepelletti, M. Seccombe, and J. Weiler (eds), Integration through Law. Europe and the American Experience, Berlin and New York: Walter de Gruyter, pp. 254-317. 
Hirsch, Barry T., and David A. Macpherson (1998), 'Earnings and employment in trucking: deregulating a naturally competitive industry', in James Peoples (ed), Regulatory Reform and Labor Markets, Norwell, MA: Kluwer Academic Publishing, pp. 61-112.

Hirsch, Barry T., and David A. Macpherson (2000), 'Earnings, rents, and compensation in the airline labor market', Journal of Labor Economics, 18, 125-55.

Kessler, Daniel P., and Lawrence F. Katz (1999), 'Prevailing wage laws and construction labor markets', NBER Working Paper No. 7574, Cambridge, MA: National Bureau of Economic Research.

Krueger, Alan B. (1991), 'The evolution of unjust-dismissal legislation in the United States', Industrial and Labor Relations Review, 44, 644-60.

Krueger, Alan B. (1992), 'Reply by Alan B. Krueger’, Industrial and Labor Relations Review, 45, 796-99.

Lee, Dwight (1996), 'European links and other odd connections - comment on Addison', Journal of Labor Research, 17, 101-03.

Levine, David I. (1997), 'They should solve their own problems: reinventing workplace regulation', in Bruce E. Kaufman (ed), Government Regulation of the Employment Relationship, Madison, WI: Industrial Relations Research Association, 1997, pp. 47597.

Luce, Stephanie (2005), 'The role of community involvement in implementing living wage ordinances', Industrial Relations, 44, 32-58.

Moore, William J., and Robert J. Newman (1987), 'The effects of right-to-work laws: a review of the literature', Industrial and Labor Relations Review, 38, 577-85.

Moore, William J. (1998), 'The determinants and effects of right-to-work laws: a review of the recent literature', Journal of Labor Research, 19, 445-469.

Neumark, David (2001), 'Living wages: protection for or protection from low-wage workers?' NBER Working Paper No. 8393, Cambridge, MA: National Bureau of Economic Research.

Neumark, David, and Scott Adams (2003), 'Detecting effects of living wage laws', Industrial Relations, 42, 531-64. 
Neumark, David, and Scott Adams (2003b), 'Do living wages reduce urban poverty?' Journal of Human Resources, 38, 490-521.

Oates, Wallace E., and Robert M. Schwab (1988), 'Economic competition among jurisdictions: efficiency enhancing or distortion inducing?' Journal of Public Economics, 35, 333-54.

Pashigian, B. Peter (1984), 'The effect of environmental regulation on optimal plant size and factors shares', Journal of Law and Economics, 27, 1-28

Pashigian, B. Peter (1985), 'Environmental protection: whose self-interests are being protected?' Economic Inquiry, 23, 551-84.

Philips, Peter, Garth Mangum, Norm Waitzman, and Anne Yeagle (1995), 'Losing ground: lessons from the repeal of nine 'little Davis-Bacon’ Acts', unpublished paper, Department of Economics, University of Utah.

Stieber, Jack, and Richard N. Block (1992), 'Comment on Alan B. Krueger. The evolution of unjust-dismissal legislation in the United States', Industrial and Labor Relations Review, 45, 792-96.

Stigler, George J. (1970), 'Director's law of public income distribution', Journal of Law and Economics, 13, 1-10.

Thieblot, Armand J. (1986). Prevailing Wage Legislation: The Davis-Bacon Act, State "Little-Davis Bacon" Acts, the Walsh-Healey Act, and the Service Contract Act, Philadelphia, PA: University of Pennsylvania Research Unit.

Tiebout, Charles M. (1956), 'A pure theory of local expenditure', Journal of Political Economy 64, 416-24.

Weiss, Harry (1935), ‘Employers’ liability and workmen’s compensation’, in John R. Commons (ed), History of Labor in the United States, 1896-1932, New York: Augustus M. Kelley

Wildasin, David E. (1989), 'Interjurisdictional capital mobility: fiscal externality and a corrective subsidy’, Journal of Urban Economics, 25, 192-212.

Wildasin, David E. (2004), 'Competitive fiscal structures’, unpublished paper, University of Kentucky.

Wilson, John D. (1986), ‘A theory of interregional tax competition', Journal of Urban Economics, 19, 296-315. 
Wilson, John D. (1999), 'Theories of tax competition', National Tax Journal, 52, 269304.

Wilson, John D., and David E. Wildasin (2004), 'Capital tax competition: bane or boon', Journal of Public Economics, 88, 1065-91.

Zabin, Carol, and Isaac Martin. 1999. 'Living wage campaigns in the economic policy arena: four case studies from California', unpublished paper, Center for Labor Research and Education, Institute of Industrial Relations, University of California, Berkeley. 